Gi respons på artikler gjennom artiklenes kommentarfelt på tidsskriftet.no.

Innleggene publiseres fortløpende på Tidsskriftets nettside og et utvalg

av innleggene publiseres også i papirutgaven i spalten «Brev til redaktøren».

Redaksjonen forbeholder seg retten til å foreta redaksjonelle endringer.

Forfattere av vitenskapelige artikler har tilsvarsrett, jf. Vancouver-gruppens regler

\section{Re: Ulike retningslinjer for behandling av prostatakreft}

Jeg leste med interesse Bjerklund Johansens kommentar om ulike retningslinjer for behandling av prostatakreft i Tidsskriftet (1). Jeg kan ikke vurdere den kritikken han fremsetter mot de norske retningslinjene, men jeg kjenner godt igjen beskrivelsen av hvordan internasjonale retningslinjer tas imot på nasjonalt nivå.

Bjerklund Johansen skriver at det ofte er forskjeller på norske og europeiske kliniske retningslinjer når det gjelder tverrfaglighet og vitenskapelige kvalifikasjoner i forfatterpanelene, arbeidsmetode og leserkrets. Ved utarbeiding av europeiske retningslinjer, gjennomgår anbefalingene ekstern internasjonal fagfellevurdering før publisering, hvilket bidrar til å unngå interessekonflikter for personer og grupper, og reduserer faren for ukritisk omtale av egen forskning og egne referanser.

I tillegg til nasjonale retningslinjer, finnes det på enkelte sykehus lokale retningslinjer. I blant finnes det til og med varierende retningslinjer innenfor samme sykehus for samme tilstand. Naturligvis kan det finnes årsaker til varierende behandling mellom sykehus på grunn av lokal kompetanse og geografi, men jeg mener det meste burde være det samme for alle pasienter. Som Bjerklund Johansen skriver: Forfattere av norske retningslinjer bør begrunne hvorfor de avviker fra internasjonale retningslinjer. Her synes jeg Danmark er et foregangsland, og spesielt innen kardiologi. Danmark er delt inn i fem regioner, som hver har en farmasøytisk komité, men det danske kardiologiske samfunnet har klart å ene hele landet til delte retningslinjer (2) som dekker nesten alle hjerte- og karsykdommer. Den danske Society of Cardiology oppdaterer disse retningslinjer hvert år, og de brukes på alle danske sykehus som nasjonale felles retningslinjer. Det oppfattes av kolleger i Danmark som en nasjonal standard av Sundhetsstyrelsen og andre offentlige etater for å referere til hva som er forsvarlig klinisk praksis.

Nå har jeg konsentrert diskusjonen på kardiologi, men jeg tror situasjonen er den samme i de fleste spesialiteter, hvilket støttes av kommentaren fra Bjerklund Johansen om prostatakreft. Det må være en enorm ødsling av resurser om lokale eksperter gjør om samme vurderinger som allerede er gjort av internasjonale eksperter som har produsert retningslinjer som har gjennomgått en omfattende ekstern, internasjonal fagfellevurdering før publisering. I tillegg er det vanligvis de mest erfarne og kvalifiserte kolleger i sine respektive spesialiteter som spanderer meget tid på denne oppgaven.

En pasient med en sykdomstilstand skal ha beste behandling uavhengig av hvor han eller hun er. Følsomhet til retningslinjer har vist på bedre resultat for pasientene (3-5). Vel gjennomarbeidede, internasjonale retningslinjer bør følges for beste medisinske resultat, men i blant trengs en tilpassing til hvert enkelt lands regulatoriske og økonomiske forhold. Slike tilpasninger bør begrunnes.

Jeg har hatt største delen av min kliniske virksomhet i Sverige og skulle ønske å kunne avslutte med hvor bra det er i Sverige, men det kan jeg ikke. Det er (nesten) like ille i Sverige. Har vi for mange eksperter?

\section{Stefan Agewall}

stefan.agewall@medisin.uio.no

Stefan Agewall (f. 1960) er overlege og professor i kardiologi ved Oslo Universitetssykehus og Universitetet i Oslo.

Ingen oppgitte interessekonflikter.

\section{Litteratur}

1. Johansen TEB. Ulike retningslinjer for behandling av prostatakreft. Tidsskr Nor Legeforen 2015; 135: 924-5.

http://nbv.cardio dk/(3.7.2015)

3. Jonathan De Blois J, Morten Wang Fagerland M, Morten Grundtvig M et al. ESC guidelines adherence is associated with improved survival in patients from the Norwegian Heart Failure Registry. Eur Heart J Cardiovasc Pharmacother 2015 $1: 31-6$.

4. Cotte $L$, Bénet $T$, Vanhems $P$ et al. The effect of adherence to guidelines for initial antiretroviral therapy on 1-year outcomes: a French cohort study. BMC Infect Dis 2014; 14: 596

5. Mehta RH, Chen AY, Alexander KP et al. Doing the right things and doing them the right way: association between hospital guideline adherence, dosing safety, and outcomes among patients with acute coronary syndrome. Circulation 2015; 131: $980-7$

\section{Re: Pasientens eller helsepersonellets helsetjeneste?}

«For første gang i historien er det laget en stortingsmelding om primærhelsetjenesten», skriver Hege Gjessing i sin leder i Tidsskriftet nr. 11/2015 (1). Men historien begynte ikke i år. For eksempel la jeg som helseminister for et par tiår siden frem en stortingsmelding om primærhelsetjenesten: St. meld. nr. 23 (1996-97) Trygghet og ansvarlighet - Om legetjenesten i kommunene og fastlegeordningen.

Men den var hverken den første eller siste stortingsmelding om primærhelsetjenesten. Primærhelsetjenesten ble heftig debattert på 1960- og 70-tallet og en rekke offentlige utredninger, innstillinger, stortingsmeldinger og lovforslag ble fremmet. Særlig viktig var naturligvis St.meld. nr. 85 (1970-71) Om helsetjenesten utenfor sykehus. I 1979 kom to viktige offentlige utredninger som omhandlet ulike sider av primærhelsetjenestene: NOU 1979: 28 Helseog sosialtjenesten i lokalsamfunnet. Oppgave og ansvarsfordeling. Finansieringsordning, og NOU 1979: 10 Helsepolitikken.

NOU-ene dannet sammen med høringsuttalelsene grunnlaget for utformingen av lovproposisjonen Ot. prp. 36 (1980-81) Om lov om helsetjenestene i kommunene, og senere Ot.prp. nr. 66 (1981-82) Om lov om helsetjenesten og sosialtjenesten i kommunene. Kommunehelsetjenesteloven ble iverksatt i 1984.

Erfaringene med loven og kommunehelsetjenestene ble drøftet i St. meld. nr. 36 (1989-90) Røynsler med lova om helsetenesta i kommunene hvor det konkluderes med at det ville være nyttig å få prøvd ut et listepasientsystem i Norge. Regjeringen fremmet forslag om en prøveordning med fast lege i fire kommuner (Ot.prp. nr. 64 (1990-91) Om lov om forsøk med listepasientsystem i kommunehelsetjenesten). Finansieringsordningene for allmennlegetjenesten ble gjennomgått i NOU 1992: 10 Finansieringsordninger for allmennlege- og fysioterapitjeneste. Og stortingsmeldingen om fastlegeordningen kom altså i 1997.

Dette er bare et utvalg. Linjer kunne trekkes enda lengre tilbake - og fremover i historien. Legeforeningens president har vel ikke allerede glemt St.meld. nr. 47 (2008-2009), Samhandlingsreformen - Rett behandling - på rett sted - til rett tid.?

Både som politisk og profesjonell aktør må Legeforeningen være vederheftig. Da kan presidenten ikke spre myter. Det foreligger flere lett tilgjengelige og gode oversikter over utviklingen - for eksempel i tidsskriftet Michael (2). Og med de staber presidenten rår over, skulle det heller ikke være så vanskelig å sjekke fakta før man griper til pennen. 
Gudmund Hernes (f. 1941) er professor ved Handelshøyskolen BI og forsker ved Fafo, og var helseminister i perioden 1995-97.

Ingen oppgitte interessekonflikter.

Litteratur

1. Gjessing H. Pasientens eller helsepersonellets helsetjeneste? Tidsskr Nor Legeforen 2015; 135: 1091

2. Michael MQ. 2013; 10:119-22. http://www.dnms.no/index.php?setPublikasjon= true\&seks_id=156998 (22.6.2015).

\section{H. Gjessing svarer:}

Takk til Gudmund Hernes for at han minner leserne om en rekke stortingsmeldinger og andre plandokumenter som Legeforeningen er kjent med. Disse dokumentene omhandlet både helse- og omsorgstjenesten, helse- og sosialtjenesten og ved en anledning - $\mathrm{i}$ hans egen tid som helseminister - en melding om legetjenesten i kommunene. Sistnevnte var en viktig milepæl for utviklingen av fastlegeordningen.

St.meld. nr. 47 (2008-2009) om samhandlingsreformen tok prisverdig for seg samhandling i hele behandlingsforløpet i og mellom tjenestenivåene i den samlede helse- og omsorgstjenesten.

Den sittende regjering har levert en stortingsmelding som den selv omtaler som den første av sitt slag, fordi den beskriver primærhelsetjenesten som en helhetlig helsetjeneste. Meldingen har som ambisjon å se de ulike deltjenestene i kommunehelsetjenesten i sammenheng og å bygge ned «siloene» mellom dem. Legeforeningen støtter intensjonen med meldingen, men har også enkelte kritiske innvendinger.

\section{Hege Gjessing}

hege.gjessing@legeforeningen.no

Hege Gjessing (f. 1972) er President i Den norske legeforening Ingen oppgitte interessekonflikter.

\section{Re: Cannabis som medisin}

Jeg har et par kommentarer og noen spørsmål til Bramness sin kronikk om cannabis i Tidsskriftet nr. 3/2015 (1). Han skriver: «En del cannabisaktivister hevder at stoffets medisinske anvendelighet taler for legalisering. Medisinsk marihuana er i USA blitt brukt som brekkstang for dette, men til tross for det som er beskrevet over, hviler mye av den medisinske bruken på et for svakt empirisk grunnlag». Men har forfatteren undersøkt hvorvidt straffereaksjoner har vært en suksess? Finnes det et eneste gyldig grunnlag for bruk av tvangsmakt rent samfunnsmedisinsk, og individuelt?

Bramness skriver også: «Men jeg tror ikke leger har en rolle i denne viktige forebyggende delen av en slik fremtid.» Jeg mener det er selvfølgelig at leger har en viktig rolle. Det er helsevesenets oppgave å bedrive opplysning og forebyggende arbeid, ikke politi og rettsvesen.

\section{Morten Alme \\ morten.alme@gmail.com}

Morten Alme (f. 1972) er selvstendig næringsdrivende/skribent. Ingen oppgitte interessekonflikter.

Litteratur

1. Bramness JG. Cannabis som medisin. Tidsskr Nor Legeforen 2015; 135: 252-3.

\section{Re: E-sigaretter - til skade eller nytte?}

Det er trist når vitenskap og personlige meninger blandes sammen, slik som i Sanner og Grimsruds kronikk om e-sigaretter og i deres svar i diskusjonen i etterkant (1). Jeg har aldri røykt og er nokså nøytral i forhold til røyking. Imidlertid er det et faktum at mange røykere har hatt problemer med å slutte, og for disse mener jeg det ville være et stort fremskritt å gå over til e-sigaretter.

Hvorvidt professor Odd G. Nilsen en gang har fått støtte fra tobakksindustrien synes jeg er helt irrelevant i diskusjonen om e-sigaretter. Dette angrepet er vel et eksempel på å ta mannen og ikke ballen når en ikke har faglige argumenter.

Jeg vil holde fast på at vår nikotininhalasjonsstudie på rotte er den beste, og kanskje den eneste, adekvate studie vedrørende e-sigaretters toksisitet. Det reises spørsmål om dosering og lengde av studien vår. Dette tyder på forfatternes manglende biologiske forståelse. To år hos rotte med en forventet levealder på tre år vil tilsvare minimum 40 års eksponering hos menneske. Hva gjelder dose nikotin, ga altså vår eksponering den doble nikotinkonsentrasjon i blod av det en finner hos storrøykere (2). Dermed skulle det ikke være noen tvil om at dose og eksponeringstid var tilstrekkelig i vår studie.

Min konklusjon er altså at det er bra å være i mot tobakksrøyking. Ut fra generelle betraktninger er det også argumenter for å advare ikke-røykere mot e-sigaretter. Imidlertid ville det være en stor helsegevinst dersom tobakksrøykere gikk over til e-sigaretter. Dersom dette hadde vært fulgt opp for lenge siden, mener jeg mange ville ha unngått alvorlige sykdommer.

\section{Helge Waldum}

helge.waldum@ntnu.no

Helge L. Waldum (f. 1946) er professor ved St. Olavs Hospital/NTNU. Ingen oppgitte interessekonflikter.

\section{Litteratur}

1. Sanner T, Grimsrud TK. E-sigaretter - til skade eller nytte? Tidsskr Nor Legeforen 2015; 135: 959-61.

2. Waldum HL, Nilsen $O G$, Nilsen $T$ et al. Long-term effects of inhaled nicotine Life Sci 1996; 58: 1339-46.

\section{T. Sanner \& T.K. Grimsrud svarer:}

«Nilsen jobbet for Philip Morris i en årrekke etter at Ekspertgruppen ble nedlagt i 1992 og hentet inn store beløp fra tobakksgiganten» (1). Artikkelen til Waldum, Nilsen mfl (2). ble sendt inn for publisering i februar 1996. Således har studien etter all sannsynlighet pågått mens Nilsen jobbet med betaling fra Philip Morris. Studiene er ikke utført etter reglene for GLP (Good Laboratory Practice) (3).

På grunn av lav følsomhet ved dyreforsøk, brukes vanligvis mange ganger høyere konsentrasjon i dyreforsøk enn det mennesker er utsatt for. I dette forsøket var konsentrasjonen av nikotin av samme størrelsesorden som hva røykere utsettes for. Vår vurdering er derfor at modellen ikke er godt egnet til å studere konsekvenser av nikotineksponering. Overlevelsen var meget lav. Både etter 1,5 år og ved forsøkets slutt var overlevelsen høyere i den eksponerte gruppen enn i kontrollgruppen ( $21 \%$ av kontrollene mot $32 \%$ av de eksponerte rottene var i live da forsøket ble avsluttet etter to år) (2). Det er angitt at $24 \%$ av rottene i kontrollgruppen mot $36 \%$ av de eksponerte dyrene utviklet svulster, men det er ingen opplysninger om tidspunkt for svulstutvikling. Det er således ikke mulig å trekke noen konklusjon fra forsøket.

\section{Tore Sanner \\ tore.sanner@kjemi.uio.no \\ Tom K. Grimsrud}

Tore Sanner (f. 1935) er professor emeritus. Han var tidligere forskningssjef ved Institutt for kreftforskning, Radiumhospitalet, og professor II ved Kjemisk institutt, Universitetet i Oslo.

Ingen oppgitte interessekonflikter.

Tom K. Grimsrud (f. 1955) er dr.med., spesialist i arbeidsmedisin og overlege/forsker ved Kreftregisteret.

Ingen oppgitte interessekonflikter. 